\title{
RECURSO ORDINÁRIO: \\ A AMPLITUDE DO EFEITO DEVOLUTIVO E O DUPLO GRAU DE JURISDIÇÃO
}

João Oreste Dalazen

Sumário: 1. Introdução. 2. Aplicação Supletiva do CPC. 3. Antecedentes legais e doutrinários. 4. Alcance do efeito devolutivo no CPC atual. 5. As formas de defesa. Conceito de mérito. 6. Relação d\% emprego e prescrição: questões de mérito. 7. O duplo grau de jurisdição. 8. Relação de emprego e prescrição no julgamento do RO. 9. Ofensa a princípios cardeais do processo. 10. A jurisprudência do STF e de outros Tribunais. 11. Conclusões.

\section{INTRODUÇÃO}

Não raro vê-se a Junta de Conciliação e Ju'gamento ou o Juízo de Direito a braços com a devolução de autos determinada por Tribunal Regional do Trabalho a fim de que "julgue o mérito: como entender de direito". Embora concebíveis várias hipóteses para tal decisão, o caso mais ccrriqueiro é aquele em que o vínculo empregatício foi negado em primeiro grau de jurisdição e reconhecido pelo Tribunal. Exemplo: "A" move ação com referência" a " $B$ " para postular verbas recisórias; a Junta ou o Juízo de Direito, acolhendo argumentação da defesa, prolata sentença declaratória negativa de improcedência ${ }^{2}$ total da pretensão por inexistência da relação de emprego; o Tribunal, ao dar provimen-

(1) Em boa técnica, não se move a ação "contra" alguém: a demanda é proposta com relação a alguém. Isso porque o autor nada pede ao réu, ou reclamado; pede, em realidade ao Estado a outorga da tutela jurisdicional acerca de um bem da vida. Dai a lição de CÂNDIDO R. DINAMARCO: "que a ação tenha por titular passivo o Estado e não o adversário é ponto iá conquistado definitivamente e pacífico na doutrina contemporânea do direito processual" ( $v$. Fundamentos do Processo Civil Moderno", ed. Rev. Trib.. 1986, pág. 117).

(2) Muitos magistrados ainda persistem no vezo de julgar carecedor da ação, o autor quando ausente o vinculo empreqatício. Há aí grave impropriedade técnica que resulta de baralharem-se conceitos tão distintos como o de leqitimidade de parte (condição da ação) e de quesțão prejudicial de mérito da causa. 
to ao recurso ordinário interposto pelo vencido, ordena a remessa doss autos ao primeiro grau de jurisdição para julgamento dos ped dos de verbas rescisórias. Igualmente não é incomum o órgão a quo declarar a prescrição do ação e, pois, a improcedência toțal da pretensão, e o Tribunal, ao reformar (rectius: substituir CPC, art. 512) a sentença, adotar idêntica providência. Trata-se de uma prática dominante no âmbito dos Tribunais do Trabalho do País, prestigiada por acórdãos de quase todas as Regiões e, inclusive, do Egrégio TST ${ }^{3}$. Ditada sob o argumento expresso, ou implícito, de evitar a supressão de um grau de jurisdição, essa prática viciosa de remeter os autos ao Juízo a quo em situações que tais: a) afronta expressa disposição legal, em virtude de equívoca compreensão do alcance do efeito devolutivo; b) contraria a lição dos mestres; c) resulta de uma errônea dedução do pr ncípio do duplo grau de jurisdição; d) conflita com princípios cardeais do processo. Eis as proposições que buscarei sustentar aqui.

\section{APLICAÇÃO SUPLETIVA DO CPC}

A Consolidação das Leis do Trabalho, na temática atinente aOs efeitos dos recursos e à sua amplitude, cinge-se a dispor que os recursos trabalhistas terão efeito meramente devolutivo (CLT, art. 899). Nenhuma palavra cortém sobre a amplitude do efeito devolutivo. Logo, omissa a CLT e não havendo qualquer incompatibilidade com seus preceitos, inequivocamente impõe-se a aplicação subsidiária ao processo trabalhista das normas do vigente Cód go de Processo Civil (CLT, art. 769).

(3) V., à guisa de exemplo, os seguintes acórdãos:

TRT - 2. ${ }^{a}$ Reg. RO - 14.793/80 - Ac. 4. ${ }^{\circ}$ T. 5.173/82, 10.05.82 (in LTr vol. 47 pág. 339, de março de 1983);

TRT - 3. ${ }^{\circ}$ Reg. RO - 2.712/80 - Ac. 1. ${ }^{\circ}$ T. 03.02 .81 (in $L T$ Tr vol. 45, pág. 989, de agosto de 1981);

TRT - 4. ${ }^{a}$ Reg. RO - 2.143/81 - Ac. 1. ${ }^{\circ}$ T. 03.11 .81 (in LTr vol. 46, pái. 217, de fevereiro de 1982);

TRT - 5. Reâ. RO - 1.456/83 - Ac. 2. 'T. 1.720/83, 03.11.83 (in LTr vol. 48 pág. 1.357 de novembro de 1984);

TRT - 6. Reg. RO - 1.625/80 - Ac. 13.11 .80 (in LTr vol. 45, pág. 852/853, de julho de 1981);

TRT - 7. Reg. RO - 1.209/84 - Ac. 737/85, (in LTr 50-2-221);

TFiT - 8. Reg. RO - 207/85 - Ac. 390/85. 19.04.85 (in LTr vol. 49, pág. 995. de agosto de 1985);

TRT - 9. ${ }^{a}$ Reg. RO - 410/82 - Ac. 2.036/82, (in DJ/PR 17.11.82);

TRT - 12. ${ }^{a}$ Reg. RO - 918/84 - Ac. $783 / 85$ 14.05.85 (in LTr vol. 50, pág. 77 de janeiro de 1986);

TST - RR - 118/81 - Ac. 3. T. 2.621/81 (in LTr 46-9-1084). 
Não há a menor dúvida de que o recurso ord'nár o está para o processo trabalhista como a apelação para o processo civil. é, em essência, uma apelação e até melhor fora assim denominá-lo: há identidade básica dos casos de cabimento e final:dade comum. Por conseguinte, inquestionável a inc'dênc:a sup'etiva na disciplina do recurso ordinário dos preceitos cue regem a amplitude do efeito devolutivo da apelação.

\section{ANTECEDENTES LEGAIS E DOUTRINÁRIOS}

É curioso observar que, retrocedendo bastante no passado, vamos encontrar no direito luso-brasileiro uma norma legal que sufragava solução diametralmente cposta da ac:ma aludida, dos Tribunais do Trabalho. No direito das vetustas Ordenações Filipinas estava expresso no Livro $3^{\circ}$, tít. 68 , no 1 , que, fosse a sentença definitiva, fosse a senteliça. interlocutória, se 0.3 julgadores

"... acharem que foi bem appe'ado, e que o appelante foi agravado pelo Juiz, assim o determinem, e não mandem tornar o feito ao Juiz, çe que foi appelado, mas vão por elle em deante, e o determinem finalmente, como acharem por direito, salvo se o appelante e o appelado ambos requererem que se torne o feito a terra..."4.

RIBAS, no séc. passado, consolidou por esta forma suscinta o direito então vigente:

"Art. 1580. No acórdão pode-se não só conhecer da justiça da apelação, como sentenciar a causa definitivamente"."

Daí a lição do grande PAULA BATISTA, ainda na segunda metade do séc. XIX, sobre o efeito devolutivo da apelação:

"Pelo efeito devolutivo a causa como que renasce na $2 .{ }^{a}$ instância, cujo tribunal fica investido de pleno direito para conhecer della 'ab integro'..."."

(4) v. "Ordenações e Leis do Reino de Portugal, Recopi'adas per mandado del Rei D. Filipe, o Primeiro", Livro Terceiro, Coimbra, Real Imprensa da Universidade. 1833.

(5) v. "Consoldação das Leis do Processo Civil", do Cons. ANTÔNIO JOAQUIM RIBAS, editada por Júlio A. Ribas Vol. II, pág. 478.

(6) v. FRANCISCO PAULA BATISTA, "Compêndio de teor'a e prática do processo civil", 3. ed., J. W. de Medeiros e Cia., Livreiros editores. pág. 234. 
Note-se que o insigne processualista pernambucano era partidário do princípio do duplo grau de jurisdição. O mesmo sucedia, entre tantos outros, como JOÃO MONTEIRO que, não obstante, ainda no limiar deste século, escrevia a propósito do tema:

"Fazer, atravez das allegações e provas produzidas na primeira instância, novo exame do julgado para o fim de resolver definitivamente o pleito - tal é a função do Juízo 'ad quem' consoante o systema do duplo grau de jurisdição. (...)

Isto, porém, não quer dizer que o segundo juízo fique restrictamente preso a todos $e$ só a todos os pontos que constituiram os motivos determinantes e o dispositivo da sentença appelada (...)

Não o é: a appelação tem por escopo corrigir o erro ou reparar a injustiça da sentença de primeiro grau; mas este erro ou esta injustiça tanto se pode concretizar de modo positivo, isto é, no que ficou explícito no dispositivo do julgado, como de modo negativo, isto é, no que deixou de ser considerado e resolvido no juízo ' $a$ quo'. Portanto, seria illidir o próprio recurso de appelaçẫo se ao appellante se negasse o direito de provocar e obter do segundo juizo, creado para reexaminar a causa, que suprisse as lacunas e omissões do primeiro julgamento"7.

Insta lembrar que esses eminentes mestres, conquanto adeptos do princípio do duplo grau, não o reputavam lesado com o aconselharem aos tribunais a resolução de questões de que o juízo a quo não cuidou. Seriam acaso incongruentes esses grandes processualistas? Não, a meu ver: apenas já entendiam, ou intuiam, que o princípio em tela não reclama o exaurimento do exame da matéria de mérito pelo órgão $a$ quo.

Sobreveio o Código de Processo Civil de 1939, que estatuía:

(...)

“Art. 811. A sentença poderá ser impugnada no todo ou em parte, presumindo-se total a impugnação quando ? recorrente não especificar a parte de que recorre".

"Art. 824. A apelação devolverá à superior instância o conhecimento integral das questões suscitadas e discutidas na ação, salvo a hipótese prevista no art. 811".

(7) JOÃO MONTEIRO, "Processo Civil e Comercial", § 228. Essa lição porém, huje, deve ser entendida em termos. como se verá adiante: o Tribunal pode julgar questões omitidas pela sentença, não pedidos não julgados. 
Como se observará adiante, o Código de 1973 praticamente em nada inovou neste passo: tão-somente enunciou de maneira mais explícita a amplitude do efeito devolutivo. Eis porque tem toda a pertinência e atualidade o magistério de JOSÉ FREDERICO MARQUES, embora lançađo ao tempo do CPC/39:

"não quer isto dizer que em segundo grau deva o Tribunal examinar apenas a sentença recorrida, para determinar se está certa ou não. Como disse Klein, a segunda instância é controle e não criação (Kontrolierend, nich Kreativ). Esse controle, porém, é sobre o litígio em sua plenitude, tal como se apresentou no Juizo 'a quo', e não apenas sobre a decisão apelada. O Juiz de segundo grau não faz 'tabula rasa' da sentença de primeira instância; no entanto, não deve limitar-se ao exame exclusivo das questões ali ventiladas, como se houvesse preclusão para $a$ análise de outros pontos de direito ou de fato que a lide suscita, mas que a decisão recorrida não abordou. O Juízo ad quem não cria novos elementos na lide a ser decidida, porquanto continua jungido às questões que foram ou podiam ser ventiladas no Juízo a quo; mas isto não quer dizer que tenha de decidir a causa verificando apenas as controvérsias que a sentença de primeiro grau procurou solucionar. A lide, em segundo grau, pode ser equacionada sob esquemas diversos dos que foram traçados na decisão da instância inferior, desảe aue o julgado ou aresto não ultrapasse os lindes do pedido. Se o exceder, estará violando o art. 4⿳0 do Código de Processo Civil, preceito esse que deve nortear a delimitação da atividade judicante também em segunda instância"s.

Daí dizer MACHADO GUIMARÃES, com absoluto acerto:

"Deve, portanto, o tribunal de apelação conhecer e julgar a causa como se fora, de acordo com a conhecida expressão, uma segunda primeira instância"9.

Essas breves referências, por si sós, prestam-se a evidenciar, para logo, que nem mesmo à luz do direito anterior justificava-se a orientação hoje agasalhada pelos Tribunais do Trabalho e acima mencionada.

(8) JOSÉ FREDERICO MARQUES, “Instituições de Direito Processual Civil”, Vol. IV, $2 .^{\circ}$ ed. 1963, n. 956, págs. 182/3.

(9) MACHADO GUIMARÃES. "Efeito devolutivo da apelação", in Estudos de Direito Processual Civil, RJ, 1969, págs. 220/1. 
A dissonância desse posicionamento frente à lei vigente e seu descompasso com a mais prestigiosa doutrina serão realçados nos tópicos seguintes.

\section{ALCANCE DO EFEITO DEVOLUTIVO NO CPC ATUAL}

Estatui, a propósito, o Código de Processo Civil:

"Art. 515. A apelação devolverá ao tribunal o conhecimento da matéria impugnada.

$\S 1$ 19. Serão, porém, objeto de apreciação e julgamento pelo Tribunal todas as questões suscitadas e discutidas no processo, AINDA QUE A SENTENÇA NATO AS TENHA JULGADO POR INTEIRO.

$\S$ 20. Quando o pedido ou a defesa tiver mais de um fundamento $e$ o Juiz acciher apenas um deles, a apelação devolverá ao tribunal o conhecimento dos demais".

Sobre a perfeita inteligência dessas normas processuais, preleciona JOSÉ CARLOS BARBOSA MOREIRA:

"A exata configuração do efeito devolutivo é problema que se desdobra em dois: o primeiro concerne à extensão do efeito, o segundo à sua profundidade. Delimitar a extensäo do efeito devolutivo é precisar o que se submete, por força do recurso, ao julgamento do órgão ad quem; medir-lhe a profundidade é determinar com que material há de trabalhar o órgão ad quem para julgar"10.

No aue pertine à extensão do efeito devolutivo, como se sabe, delimita-se pela extensão da impugnação, segundo o consagrado princípio romano tantum devolutum quantum appellatum. É o que consta do caput do art. 515. Sob esse aspecto, portanto, se o recur o é parcial (impugna-se apenas um, ou alguns dos capítulos da sentença em que sucumbiu o litigante), também parcial é a devolução; se o recurso é total, a cognição do tribunal igualmente será plena.

Sob o aspecto da profundidade, seja parcial, ou total o recurso, é sempre amplíssima a devolução, como deflui dos $\S \S 1$ e 2.9 do art. 515. Quer dizer, não se afastando da matéria impugnada, o conhec mento do tribunal é sempre pleno, integral, não se circunscrevendo às questões realmente decididas em primeiro grau, mas "também às que poderiam tê-lo sido". Assim, sempre nos

(10) V. Comentários ao Código de Processo Civil, Forense, Vol. V 1976. pág. 403. 
limites da impugnação do apelo, como reza a lei, todas as questões' suscitadas e discutidas no processo referentes quer ao(s) fundamento(s) do pedido, quer ao(s) da defesa, mesmo que não julgadas por inteiro pela senteriça, serão novamente conhecidas pe o tribunal. Igualmente aquelas apreciáveis de ofício e as questões jurídicas ${ }^{11}$. Daí o exemplo oportuno do prof. BARBOSA MOREIRA:

“... se o réu opusera duas defesas, e o Juiz julgou improcedente o pedido, acolhendo uma única dentre elas, a apelação do autor devolve ao órgão ad quem o conhecimento de ambas: o pedido poderá ser declarado improcedente, no julgamento da apelação, com base na defesa cue o órgão a quo repelira, ou sobre a qual não se manifestara. Se o Juiz julgou procedente o pedido, rejeitando a defesa $a$ e omitindo-se quanto à defesa $b$, a apelação do réu permite ao tribunal, sendo o caso, julgar improcedente o pedido, com apoio seja em $a$, seja em $b " 12$.

Do exposto, segue-se que, em se tratando de recurso interposto contra sentença terminativa - isto é, de pronunciamento decisório que põe termo ao procedimento de primeiro grau sem julgar o mérito - o tribunal, dele conhecendo, unicamente deverá perquirir se andou bem, ou não, o Juízo a quo ao extinguir o processo sem equacionar a lide. Naturalmente porque apenas esta é a matéria impugnada e, pois, objeto de devolução ao tribunal. De sorte que não será dado ao juízo ad quem, se der provimento ao recurso, ato contínuo adentrar no exame do mérito da causa. Nesse caso, o provimento do apelo necessariamente implicará a restituição dos autos ao Juízo a quo para que dê seqüência ao procedimento. Tal se faz necessário, como assinala CHIOVENDA, "porquanto faltou por inteiro o primeiro grau de jurisdição quando o primeiro juiz deciarou não pođer manifestar-se sobre o mérito"13.

Solução idêntica comporta o caso de anulação, por error in procedendo da sentença definitiva, isto é, da que põe termo ao procedimento de primeiro grau com julgamento de mérito. Nessa circunstância, como ensina o Prof. BARBOSA MOREIRA, "se o órgão ad quem acoihe a impugnação, dando provimento ao recurso, deixa de existir pronunciamento de primeiro grau sobre o mérito (...) A apelação terá desempenhado função meramente rescindente. (...) O Juiz a quo tem de proferir nova sentença

(11) BARBOSA MOREIRA, ob. cit., pág. 418.

(12) ob. cit. pág. 419.

(13) GIUSEPPE CHIOVENDA, “Instituições de Direito Processual Civil” Vol. III, Saraiva, 1965, 2. ed., pág. 255. 
para "cumprir e acabar o ofício jurisdicional" (art. 463). Não é lícito ao tribunal, após anular a decisão apelada, ingressar no exame do mérito"14.

Atente-se, porém, para o fato de que nos dois casos acima figurados a tônica é a ausência total de pronunciamento sobre o mérito da causa pelo juízo a quo, ou porque sequer foi iniciada (sentença terminativa), ou porque o ju'gamento de mérito levado a cabo foi cassado (sentença definitiva anulada). Então, sim, justifica-se o retorno dos autos ao juízo de origem para que prof'ra sentença de mérito. Julgar a causa originariamente em segundo grau importaria, de fato, abolir o duplo grau de jurisdição.

Bem diversa, todavia, é a situação quando o recurso ordinário é interposto contra sentença definitiva, cuja validade, como ato processual em si mesmo, não se pôs em xeque. Aqui se devolve ao conhecimento do órgão ad quem o mérito da causa, em todos os seus aspectos, obviamerite na extensão da impugnação. $\mathrm{Na}$ liç̃̃o do nunca assaz citado mestre BARBOSA MOREIRA (grifei) :

"Dirige-se a impugnação contra o pronunciamento do juízo inferior, que julgou procedente ou improcedente o pedido. Assim, em princípio, compete igualmente ao tribunal proferir decisão de procedência ou de improcedncia, ainda que a sentença apelada não haja chegado a examinar todo o conteúdo da lide. Por exemplo: se o órgão a quo, após a audiência de instrução e julgamento, deu pela ocorrência da prescrição, que já é matéria de mérito (cf. art. 269, no IV), pode o tribunal, negando a prescrição, passar a apreciar os restantes aspectos da lide, sobre os quais o juiz não chegará a pronunciar-se. Não há aqui propriamente exceção à regra, segundo a qual a extensão do efeito devolutivo se mede pela extensão da impugnação. A 'matéria impugnada' é a declaração da improcedência do pedido, e sobre isso há de manifestar-se o tribunal, muito embora, para fazê-lo, tenha de examinar questões que o órgão a quo deixou intactas. $\dot{E}$ o que se infere to $\S 1$ do dispositivo ora comentado..."15.

$\mathrm{E}$, mais adiante, arremata $\mathrm{o}$ eminente processualista e desembargador carioca:

(14) ob. cit. pág. 417.

(15) ob. cit., págs. 415/416. 
“... é inadmissível que o órgão superior se pronuncie sobre o meritum causae, sem oue antes o tenha fe:to o juízo inferior. Não é necessário, porém, que a atividade cognitiva deste haja esgotado a matéria de mérito. $O$ principio do duplo grau, no sistema do estatuto vigente, não reclama que só passem ao cxame do tribunal as questões efetivamente resolvidas na primeira instância. fica satisfeito com a simples possibilidade de que essas questões fossem legitimamente apreciadas ali. Deve reconhecer-se tal possibilidade sempre que o juiz a quo já estivesse em condições de resolvê-las, no momento em que proferiu a sentença"15.

Comunga desse entendimento o preclaro JOSÉ FREDERICO MARQUES $^{16}$ :

"Opera-se a devolução total da causa ao Juíco 'ad quem': a) quando, por ter havido sucumbencia por inteiro do autor, ou do réu, o vencido apela contra toda a sentença; b) quando, malgrado se tenham registrado susum sências parciais, os recursos de todos os vencidos, por somados e reunidos, acabem clevolvendo integralmente ao tribunal de segunda instância, o conhec mento total do litígio, com aue a devolução pıena se opera por adição. Em havendo devolução plena, o Jui o 'ad quem', para prestar a tutela jurisdicional, encontra-se em idênt ca posição à do órgão do Juízo 'a quo' quando tem de proferir a sentença. Sustenta LIEBMAN, aliás, que o tribunal poderá submeter a exame todas as questões que se suscitaram em primeira instäncia, mesmo as que o primeiro juiz eventualmente deixou de ju!gar, o que mereceu consagração da legislação em vigor, ... (art. 515, $\S 10$ "’).

Por conseguinte, à vista dessas considerações, afigura-se-me correto inferir que, atendo-se à matéria impugnada no recur.so, o tribunal, conhecendo do apelo, para julgá-la no mərito devera lançar mâo de todas as questões de fato e de dire to devatidas no processo, mesmo que não apreciaclas integralmente pe ${ }_{i} a$ seniença. Pode ainda, no caso de multıplicidade de fundamentos para 0 pedido ou a defesa, sempre nos lindes do(s) capítulo(s) atacado(..) da sentença, alterar-lhe a motivação, ou dar aos fatos nova qualificação jurídica. De modo çue, em síntese:

(16) v. Manual de Direito Processual Civil, $3 .^{\circ}$ Vol., Saraiva 7.॰ ed., 1985, pág. 137. 
a) do ângulo da extensão do efeito devolutivo, a atividade cognitiva do tribunal estará demarcada pelo âmbito da impugnação; assim, o tribunal, no máximo, rejulga os pedidos já dirimidos pelo juízo a quo; não julga os pedidos que este não julgou; portanto, não "completa" o tribunal o julgamento dos pedidos sobre os quais se omite a sentença citra petita ${ }^{17}$;

b) do ponto-de-vista da profundidade do efeito devolutivo, para o julgamento do(s) capítulo(s) impugnado(s) da sentença o "material" de que se louvará o Juízo ad quem compreende, além das questões examináveis de ofício (nulidades, p.e.), todas as questões invocadas e debatidas pelas partes no processo, ainda que não apreciadas totalmente pela sentença; por isso se diz que sob este prisma a devolução é sempre plena, ou integral.

Perceba-se, como já enfatizado, que a extensão da devolução será distinta conforme haja ocorrido, ou não, pronunciamento decisório do mérito da causa pelo juízo a quo. Insista-se: em sendo terminativa a sentença, não se devolve ao tribunal o exame da lide; em sendo definitiva e válida a sentença, ao revés, o tribunal rejulga a causa na extensão da impugnação.

Desse modo, o perfeito deslinde da questão aqui aflorada requer um prévio exame do conceito de mérito da causa e, notadamente, se é de mérito a sentença que julga inexistente a relação de emprego, ou consumada a prescrição extintiva. É o que akordarei a seguir, como premissa necessária da resposta ao problema inicial.

\section{FORMAS DE DEFESA. CONCEITO DE MÉRITO.}

Inspirado em LIEBMAN, ensina CALMON DE PASSOS que "duas relações coexistem no processo: a relação continente, denom'nada de relação processual" (...) e "a relação conteúdo, isto $\dot{e}$, a re ação que se constitui objeto de toda a atividade processual (a lide) denominada, no processo, de mérito, expressa pela causa

(17) A sentença "citra petita" é um ato processual formalmente defeituoso: padece de vício procedimental. Se não interpostos embargos declaratórios oportunamente, toca ao tribunal anulá-ia e restituir os autos ao Juizo "a quo" para que decida sobre tcdos os pedidos. Não cabe ao tribunal, em pronunciamento integrat:vo, "complementar" a sentença. Não se pode impugnar o que não se conh€ce. Assim. na sentença "citra petita" não há devolucão ao tribuna! a respeito dos pedidos não equacionados (CPC, art. 515). Solucionálos diretamente o tribunal implicaria, sim, infracão ao princípio do duplo grau de jurisdição. 
de pedir e pelo pedido formulado na inicial"1s. Essa duplicidade projeta-se na elaboração da clefesa, que igualmente pode ser voltada à relação processual e/ou à relação jurídica de direito material subjacente à lide.

A defesa em que se ataca o process denomina-se defesa indireta processual. Por meio desta busca-se "indicar fatos extintivos da relação processual ou impeditıvos quer da sua constituição, quer do seu desenvolvimento válido e regular"18, ałegandose questões preliminares como a ausência de qualquer dos pressupostos processuais, ou que não concorre qualquer das condições da ação.

A defesa pela qual o sujeito passivo da relação processual rebate e resiste à pretensão deduzida no pedido do autor, visando a informar-lhe os fundamentos de fato ou de direito, denomina-se defesa de mérito.

Através da defesa de mérito impugna o rón o prónr:o pedido do autor, a fim de evidenciar a sua improcedênc:a. Controvertese acerca da relação jurídica "conteúdo" de que fala CALMON DE PASSOS ou de um fato da vida nela fundado.

"A defesa de mérito", preleciona FREDERICO MARQUES, "apresenta vários matizes e formas. E'a vai derde a impugnação 'simplex' do pedido do autor até a afirmação de fatos peremptórios capazes de impedir que prospert a pretensão em juízo"19. A defesa de mérito, como ensina a doutrina, pode ser direta ou indireta. Aquela se dá quando o réu refuta os fatos constitutivos do pedido, ou então, sem negar a veracidade dos fatos, impugna as conseqüências jurídicas pretendidas pelo autor. A defesa indireta de mérito verifica-se quando "o réu deixa íntegros os fatos do autor, mas opõe fatos novos, com eficácia extintiva ou impeditiva da pretensão do demandante". Nesta modalidade figuram entre outras, as chamadas "exceções de direito material", como a prescrição e a compensação ${ }^{20}$.

(18) JOSÉ JOAQUIM CALMON DE PASSOS, "Comentáros ao Códiqo do Processo Civil", Forense, II Vol. 3." ed., páqgs. 326/327. O ilustre mestre baiano abeberou-se, neste passo, em idêntica lição de LIEBMAN in "Estudos sobre o Processo Civil Brasileiro", Saraiva, 1947, pág. 125.

(19) JOSÉ FREDERICO MARQUES. "Instituições de Direito Processual Civil", vol. III, Forense, 3.` ed., pág. 121.

(20) JOSÉ FREDERICO MARQUES, "Instituiç̃es de Direito Processual Civil", Vol. III. Forense, 3." ed., pág. 121. 
A defesa direta de mérito pode consistir numa questão prejudicial ${ }^{21}$. Como frisou ALFREDO BUZAID, não raro a defesa consiste em impugnar não só o pedido, como também a existência da relação jurídica posta pelo autor, expressa ou tacitamente, como fundamento de sua ação $0^{22}$. O conceito de questão prejudicial, sumamente relevante aqui, é ministrado pelo insigne prof. JOSÉ FREDERICO MARQUES (grifei) :

"Prejudicial, portanto, é a relação ou situação jurídica a cuja existência se subordina, no tocante a seu próprio conteúdo, o pedido que o juiz deve decidir, através de sentença, para resolver a lide ou "rés in indicium deducta". (...)

O pressuposto necessário, portanio, que há na prejudicial, como antecedente do litígio a ser resolvido, tem conteúdo determinado, certo e perfeitamente definido: ele é sempre relação jurídica ou direito subjetiro de cuja existência depende o julgamento da lide. Dai se segue que a prejudicial diz respeito ao mérito, por que se trata de direito ou relação jurídica de cuja existência ou inexistência depende o julgamento do litígio, isto é, daquilo que constituirá objeto de sentença definitiva"'23.

Para o CPC vigente, prejudicial, é a questão que "constitui pressuposto necessario para o julgamento da lide" (art. 470), como a controvérsia pertinente à "relaçáo jurídica de cuja existéncıa ou inexıstêncıa depender o julgamento da lide" (art. 50). for sua vez, o art. 325 preceitua que se trata do "direito que constitui fundamento do pedido do autor" e do qual depende, "no todo ou em parte, o julgamento da lide".

A questăo prejudicial envolve um juízo prévio que, como o próprio nome sugere, pode prejudicar a soluçào da questão princıpal ${ }^{-4}$. Caracterızam-na os seguintes elementos: a) antecedência logıco-juıídica (o restante do mérito da causa fica condicionado

(21) Não confundir questão prejudicial com questão preliminar, como costuma ocorrer na doutrina e na jurisprudência. O CPC distingue-as nit.damente. A quesião preliminar diz respeito à reiação processual ou às condições de exercício da ação, sendo, "destinada a impedir processo contra legem" (23). Acolhendo-a, o juiz extingue o processo sem julgar a lide (CPC, ART. 276). A prejudicial, por sua vez, concerne ao mérito da causa.

(22) ALFREDO BUZAID, "Ação Declaratória no Direito Brasileiro". pág. 187.

(23) JOSÉ FREDERICO MARQUES "Manual de Direito Processual Civil", 3. Vol. 2. parte, Saraiva, 1985, págs. 52 e 54.

(24) HÉLIO TORNAGHI observa, com a costumeira acuidade, que a questão principal é "necessariamente subordinada" e. por isso, "é um paradoxo que se chame principal a uma questão subordinada a outra". V. "Instituições de Processo Penai", Vol. II 1.` ed. 1959. Forense, pág. 366. 
à resolução dessa questão prévia); b) pode existir de forma autônoma, isto é, sem o traço de ર̂rejudicialidade a outra em processo específico, como questão principal. (p.e., a ação declaratória prevista no art. 4 o do $\mathrm{CPC}$ ).

Ilustre-se com o exemplo de BARBOSA MOREIRA: a controvérsia sobre a existência ou inexistência da obrigação alimentar terá este ou aquele desfecho conforme se resolva que ex.ste ou não existe relação de parentesco até certo grau ${ }^{25}$.

"Mutatis mutandis", o mesmo sucede com a controvérsia sobre a presença, ou não, de relação de emprego, suscitada incidentalmente pelo "reclamado" no processo trabalhista. Do equacionamento prévio desta questão dependerá o acolh mento, ou não, dos pedidos formulados com esteio em contrato de emprego.

Ressalte-se que a doutrina não dissente de que a questuo prejudicial é sempre matéria de mériio ${ }^{26}$, tanto que poderia ser objeto de processo autônomo ${ }^{27}$.

$\mathrm{E}$ qual é, então, o conceito de mérito? Mérito é o mesmo que lide, como esclarece o prof. ALFREDO BUZAID na exposição de motivos do atual CPC. Por isso, acentua LIEBMAN, por todos (grifei) :

"julgar a lide e julgar o mérito são expressões sinônimas que se referem à decisão do pedido do autor para ju gá-lo procedente ou improcedente e, por conseguinte, para conceder ou negar a providência requerida".

$\mathrm{E}$, mais adiante, na mesma obra, assinala o grande luzeiro da Processualística moderna:

"o conceito de mérito, do ponto-de-vista do processo tornou-se agora bem claro: incluem-se nele todas as questões que, de qualquer forma, se refiram à controvérsia existente entre as partes e submetida ao conhecimento do juiz, cuja resolução pode levar ao julgamento do pedido, para acolhê-lo ou rejeitá-lo, ou (lembramos as lavras

(25) JOSÉ C. BARBOSA MOREIRA, artigo in "Repertório Enciclopédico Brasileiro" n. ${ }^{\circ} 39$, Editor Borsoi, páq. 32.

(26) Além de JOSÉ F. MARQUES, já citado, consultem-se. HÉLIO TORNAGHI, ob. cit.; BARBOSA MOREIRA, artigo referido acima; LIEBMAN nota, in "Instituições de Direito Processual Civil", de GIUSEPPE CHIOVENDA, 1. Vol., Saraiva, 1965. pág. 393.

(27) É o que já ponderava o prof. JOSÉ ALBERTO DOS REIS: “a... questão pre. judicial constitui objeto próprio de uma causa distinta". V "Comentários ao Código de Processo Civil", 1945.

Hoje a lei é expressa ao cuidar da ação declaratória principal (CPC, art. 4.) e incidental (CPC arts. 5. e 325). Evidentemente, no primeiro caso, deixa de ser questão prejudicial. 
de antigo jurisconsulto) para condenar ou absolver o réu. Não fazem parte do mérito as questões que dizem respeito ao processo..." 28 .

Portanto, af gura-se acertado concluir que o órgão judicante decide o mérito da causa quando examina qualquer aspecto da defesa direta ou da defesa indireta de mérito, como acima exposto, para acolher ou rechaçar o(s) pedido(s) deduzido(s) pelo autor.

\section{RELAÇÃO DE EMPREGO E PRESCRIÇÃO: QUESTŌES DE MÉRITO}

Salta aos olhos que a relação de emprego e a prescrição são questões pertinentes ao mérito da causa.

No que tange à disputa sobre a existência, ou não, de relação de emprego, quando suscitada incidentalmente no processo trabalhista (a contestação nega o vínculo empregatício), assume feição típica de questão prejudıcial o que significa dizer matéria referente ao mérito. Com efeito, se o "reclamante" postula $13^{\circ}$ salár:o e férias, alegando a existência de contrato de emprego, e o "reclamado" nega a existência deste contrato, afirmando ser de natureza mercantil a relação jurídica entre ambos (p.e., contrato de representação comercial), de duas uma: ou o "reclamado" nega os fatos constitutivos da relação jurídica que embasa a pretensão do "reclamante" (abor não subordinado, serviço eventual, etc.), ou nega a conseqüência jurídica pugnada pelo autor (náo nega os fatos narrados na peça exordial, mas refuta que configurem relação jurídica de emprego). Em qualquer hipótese, estaremos em face de uma defesa direta de mérito ${ }^{29}$. Desse modo, o "reclamado" estará repelindo os pedidos de férias e 13 ọ salário porque 0 reclamante não é sujeito da relação de emprego que enseja o pagamento daquelas prestações. Quer dizer, fere-se assim o âmago da questão de fundo, negando-se seus próprios fundamentos. Ora, da solução da controvérsia em torno do vínculo empregatício depende o sentido em que se há de equacionar os ped dos de férias e gratificação natalina. Percebe-se aí o vínculo de dependência lógica - um dos aspectos característicos da questão prejudicial - eiıtre a resoluçâo da primeira questão (vínculo empregatício) e a da segunda (prestações dele decorrentes). Conforme seja resolvido o primeiro problema fica totalmente predeterminado o modo pelo qual se resolverá o segundo. Ou seja: a decisão sobre a primeira questão pode implicar prejulgamento da

(28) ENRICO TULLIO LIEBMAN, "Estudos sobre o Processo Civil Brasileiro", Saraiva 1947. págs. 137 e 194/195. 
outra, prejudica a outra. Por isso a questão prejudicial requer sempre exame prévio: se, no exemplo, for negada pelo órgão jurisdicional "a quo" a relação de emprego, obviamente estarão prejulgados os pedidos de férias e 13ํ salário. Mas note-se: foram julgados e rejeitados, no mérito! Prejulgamento não significa ausência de julgamento.

Essa a mais prestigiosa doutrina, aceita, no direito pátrio, entre outros por COQUEIJ̈O COSTA ${ }^{29}$ є ANTÔNIO LAMARCA ${ }^{30}$. Para espancar qualquer dúvida, essa orientação que logrou obter a fiança, altamente valiosa do imortal CHIOVENDA (grifei):

\begin{abstract}
“Constituirá 'questão prejudicial' a questão sobre a existência de uma relação jurídica com obrigações em quotas periódicas, suscitada no processo em que se cobra a prestação. Entre as relações jurídicas complexas ocupam lugar especial as com obrigações em quotas periódicas: tais são os débitos pagáveis por partes, ou a prazos (locações de coisa ou de obra, relação de emprego, prestações de aluguel, pensões alimentícias, impostos, mútuos, e outros). Cada prestação em si pode constituir objeto de demanda e processo; e, na ocasião da demanda de uma prestação, pode cogitar-se uma questão prejudicial sobre a relação jurídica, em virtude da qual a prestação é exigida"si.
\end{abstract}

Sucintamente, pois: a negativa da relação de emprego "incidenter tantum" configura defesa direta de mérito que suscita no processo uma questão prejudicial. Equacionando-a, o órgão juriscicional estará julgando o mérito da causa, no todo ou em parte.

No tocante à prescrição (defesa indireta de mérito ou exceção de direito material), a lei brasileira é expressa no sentido de que ao pronunciá-la (tal como sucede com a decadência) o juiz profere sentença de mérito (CPC, art. 269, IV). Andou bem o legislador, neste passo, seja porque tomou partico na crucial disputa que havia a respeito ao tempo do Código de 1939. (com

(29) V. COQUEIJO COSTA, “Direito Judiciário do Trabalho", Forense, 1978, págs. $82 / 83 / 84$. No mesmo sentido, v. "Repercussões do Novo CPC na Justiça do Trabalho" in LTr 38/5. Vale observar, porém, que o preclaro Ministro do TST. conquanto entenda ser "objeto de mérito" a questão alusiva à existência de relação de emprego, conclui - equivocamente, a meu ver - que daí decorre ou não a "carência de ação". Confundem-se, como se vê, mérito da causa e condição da ação.

(30) V. ANTÔNIO LAMARCA, "A Ação na Justiça do Trabalho", Edições Trabalhistas, Rio $1^{\circ}$ ed., pág. 9.

(31) V. GIUSEPPE CHIOVENDA, "Instituições de Direito Processual Civil”, 1. Vol., Saraiva, 1965, 2.' ed., pág. 390. 
implicações no recurso cabível, ação rescisória, etc.), seja porque adotou a solução que me parece corret́a. Sim, porque a prescrição, implicando a perda do direito de ação, por via de conseqüência leva à extinção também do próprio direito subjetivo material.

Lastreado sobremaneira em LIEBMAN, o CPC vigente acatou a boa doutrina esposada pelo mestre peninsular já na década de 40:

“... questão de mérito é toda questão que se refere à existência da relação litigiosa e à procedência da pretensão do autor, isto é, em outras palavras, ao próprio objeto do processo, e inclui indubitavelmente a prescrição: esta torna-se, então, entre as 'questões de mérito' a que deve ser examinada em primeiro lugar"32.

Vimos, assim, que o exame da controvérsia sobre relação de emprego e prescrição envolve pronunciamento jurisdicional de mérito. Imperioso agora, também como premissa necessária à solução do problema inicial, avaliar, ainda que a vôo de pássaro, como se deve entender e aplicar o princípio do duplo grau de jurisdição.

\section{O DUPLO GRAU DE JURISDIÇÃO}

O princípio da duplicidade de graus de jurisdição, imanente em nosiso Direito, é realizado, todos sabemos, pelo recurso ordinário no processo trabalhista e pela apelação no processo civil. Mas em que consiste? Di-lo CHIOVENDA (grifos do autor):

“... consiste em que toda causa, com exceção dos casos enumerados na lei, deve poder transitar pela plena cognição de dois tribunais sucessivamente (...)

Mediante a apelação, conduz-se a causa decidida pelo juiz inferior ao juiz superior. Confere-se a este a mesma cognição plena do primeiro juiz; a dizer, examina a causa sob todos os aspectos que podiam constituir, para o primeiro juiz, objeto de exame. A cognição do segundo juiz (...) tem por objeto, aparente ou imediatamente, a sentença do primeiro juiz, que se deverá declarar justa ou injusta, de fato ou de direito; na realidade, contudo, tem por objeto a relação decidida, sobre a qual o segundo juiz é convocado a estatuir ex novo..."32.

(32) V. ENRICO TUlLIO LIEBMAN. "Estudos sobre o Processo Civil Brasileiro", Saraiva. 1947, págs. 192/193.

(33) V. GIUSEPPE CHIOVENDA, "Instituições de Direito Processual Civil", Saraiva, 1965, Vol. III, pág. 246. 
Atente-se para o fato de que o inolvidável mestre italiano não diz que a concretização do duplo grau requeira reexame das questões decididas pelo jlízo "a quo" e somente destas. Ensina, sim, que deve haver "plena cognição" da causa, sucessivamente, o que vale dizer: os pedidos julgados pelo juízo "a quo", havendo recurso do litigante sucumbente, nos linites da impugnação, são reexaminados pelo juízo "ad quem", dinda que para tal lance mão de questões resolvidas ou omitidas pela sentença, pois o tribunal não julgará a sentença, mas a causa ${ }^{34}$.

Por isso, e ainda mais explícito, preleciona o insigne processualista (grifei) :

"O juiz de apelação encontra-se em face da demanda na mesma condição em que se encontraria o juiz de primeira instância no momento da decisão; assistem-lhe os mesmos poderes (supra, no ${ }^{\mathrm{s}} 258$ e segs.). Se a demanda foi rejeitada em primeira instância, e o autor passa, portanto, a apelante, o juiz da apelação reexamina sob todas as faces $a$, demanda, e pode, pelo contrário, acolhê-la, já por entender, em divergência com o primeiro juiz, afirmados e provados todos os fatos constitutivos, $j a$ a por excluir qile estejam afirmados e provados fatos impeditivos ou extintivos considerados tais pelo primeiro juiz. Pcde, por sua vez, a demanda acolhida pelo primeiro juiz vir a ser, na apelação, quando apelante o réu, rejeitado, por força de razões inversas. Evidentemente, poderá acontecer que o juiz da apelação se ocupe de questões não examinadas pelo primeiro; por exemplo: rejeita a demanda por prescrição, ao passo que na prime'ra instância fora rejeitada por vício de consentimento e sem o exame, portanto, das exceções subordinadas. A necessidade do duplo grau de jurisdição entende, pois, com as demandas e não com as simples questões"35.

(34) É o magistério do próprio CHIOVENDA, em outro volume de sua monumental obra: "objeto do exame do juiz de sequndo grau não é a sentença de primeiro grau, mas diretamente a relação jurídica controvertida" (ob. cit., Vol. II, pág. 100). Comunga desta orientação LIEBMAN: " ... não significa, todavia, que a função do Tribunal de Apelação se adscreva ao controle da sentença do primeiro juiz para estabelecer se está certa ou errada. Mesmo no direito brasileiro o objeto do recurso de apelação é a controvérsia que se deduz no processo e que novamente se deve decidir" (nota in CHIOVENDA. "Instituições", Vol. III, páq. 249).

(35) V. CHIOVENDA, ob. cit., Vol. III, págs. 251/252. 
Eis aí o aspecto fundamental do problema aqui pasto: a exigência do duplo grau diz respeito às "demandas" e não "com as simples questões". Ora, demanda, na linguagem peninsular ${ }^{36}$, segundo o próprio CHIOVENDA, "se resolve em três elementos necessários e essenciais: sujeitos, objeto e causa" 37 . Ou seja, a demanda deve conter, além das pessoas, o pedido (objeto) e a causa de pedir. Porque contém o pedido ("petitum") e este é seu traço mais saliente, CHIOVENDA, em várias passagens de sua obra, emprega o vocábulo demanda na acepção de pedido. Alude, por exemplo, a "receber a demanda" 38 no sentido inequívoco do que hoje designamos por acolher o pedido; alude também a "rejeitar a demanda" 3 s no sentido induvidoso do que a terminologia atual designa por rejeitar o pedido.

De sorte que quando CHIOVENDA assevera o duplo grau "entende com as demandas", parece-me que, sem sombra de dúvida, quer significar que o duplo grau diz respeito aos pedidos, não às questões suscitadas no processo. Vale dizer: o tribunal não pode conhecer diretamente, como regra, de pedidos não julgados pelo primeiro grau, mas pode e deve julgar "todas as questões suscitadas e discutidas no processo, ainda que a sentença não as tenha julgado por inteiro", como reza expressamente nossa lei (CPC, art. 515, § 10). Em outras palavras, o tribunal não aprecia pedidos não julgados pelc juízo "a quo" (não pode, assim, "completar" a sentença "citra petita"), mas deve enfrentar, no exame da matéria impugnada objeto de devolução, questões não equacionadas pelo primeiro grau, havendo-se por questão "o ponto de fato ou de direito sobre que dissentem os litigantes" 39 .

(36) A palavra "demanda" é empreqada no direito processual civil brasileiro atual no sentido de "causa", "pleito", ou "iprocesso" (V.p.e.. art. 70, III: "demanda capaz de reduzir... à insolvência"). Mas o vocábulo "demanda" é empregado em sentido diferente na Itália e Alemanha, tal como sucedia com nossos antigos processualistas. Na Itália distinquem-se "azione" e "domanda". "A primeira é o poder, ou direito de provocar o provimento jurisdicional; a segunda expressa o ato através do qual o provimento é postulado" (cf. CANDIDO DINAMARCO, "Fundamentos do Processo Civil Moderno", Ed. Rev. Trib. 1986, páq. 129). Assim, a demanda é o ato postulatório pelo que se exerce o direito de acão. Por isso, na Itália, fala-se em propositura da "domanda", não da "azione". Claro que com este último significado o vocáburlo é utilizado por CHIOVENDA no texto.

(37) V. ob. cit., $1^{\circ}$ Vol., páq. 354.

(38) Ob. cit.. 1. Vol., pág. 158. Afirma CHIOVENDA textualmente: “receber a demanda do autor significa atuar a lei a seu favor (...), isto é, afirmando a existência de uma vontade de lei que qarante um bem ao autor ou neqando a existência de uma vontade de lei que qaranta um bem ao réu. Semelhante_ mente, rejeitar a demanda significa atuar a lei a favor do réu (...)".

(39) V. HUMBERTO THEODORO JUNIOR, "Curso de Direito Processual Civil", Vol. I, Forense, 1985. pág. 558. 
Sobre a importantíssima opinião de CHIOVENDA acima, LIEBMAN ao anotar a obra de seu mestre, não apenas frisou ser aplicável ao direito brasileiro como também a endossou:

"Observada, pois, a proibição de formular novas questões de fato, pocierá o Tribunal de Apelação submeter a exame todas as questões que se suscitaram na primeira instância, mesmo as que o primeiro juiz eventualmente deixou de julgar. Por exemplo: formuladas pelo réu várias defesas independentes entre si e acolhida em primeiro grau aquela que, na ordem lógica, se apresentara como a primeira, o Tribunal, se decide diferentemente a primeira questão, pode passar ao exame das outras" ${ }^{40}$.

N'outra obra, discorrendo especificamente sobre a "decisão que decreta a prescrição", LIEBMAN retomou o tema para esclarecer (grifei):

"O principio do duplo grau exige que o mérito da causa possa ser apreciado e julgado - 'no seu conjunto' duas vezes por juízes diversos, não, porém, que todas as questões discutidas, e cada uma delas, sejam decididas duas vezes sucessivamente"41.

Nesse mesmo estudo, para sepultar qualquer dúvida relativamente ao assunto, LIEBMAN aduz (grifei):

“... conhecendo o recurso de apelação e dando-lhe provimento, o Tribunal, depois de decidir não prescrita a ação deve ele mesmo julgar o mérito definitivamente" "1.

Bem se vê, pois, que por este raciocínio, "mutatis mutandis", se o Tribunal do Trabalho, no julgamento do recurso ordinário, civergindo da Junta ou Juízo de Direito, entende que se caracterizou o vínculo empregatício ou que inocorreu prescrição, deve prosseguir no julgamento, solucionando as demais questões do litígio, conforme, a seu ver, seja de direito, para acolher ou rejeitar os pedidos.

(40) Nota in CHIOVENDA, "Instituiçōes de Direito Processual Civil", 1965, Saraiva, Vol. III, pág. 252.

(41) V. ENRICO TULLIO LIEBMAN: "Estudos sobre o Processo Civil Brasileiro", Saraiva, 1947, págs. 190/191. 
Em suma: para a realização do princípio do duplo grau não se requer que o juízo "a quo" haja exaurido a matéria de mérito no julgamento da lide. Eesta que haja julgado o(s) pedido(s).

Dessa maneira, o duplo grau não é um princípio absoluto e inflexível no sentido de que apenas as questões realmente decididas pelo órgão inferior são submetidas ao superior. Isso não passou despercebido à argúcia de CHIOVENDA. Referindo-se a casos análogos aos de que aqui cuidamos - reforma de "sentença interlocutória ou isscidental", p.e. - enfatizou o mestre:

"Em todos esses casos, a necessidade de fazer prosseguir a causa dá lugar ao problema de se o prosseguimento deve efetivar-se perante o Juiz de primeira ou de segunda instância. Entram em conflito, aqui, dois princípios: o princípio do duplo grau de jurisciição, que em sua mais conseqüente aplicação, conduziria em remeter a causa, em todas as hipóteses, ao primeiro Juiz; e o princípio da economia dos processos, pelo qual o legislador se inclina, hoje, a temperar o rigor do primeiro princípio, com impor ou permitir ao segundo Juiz o julgamento da causa, contentendo-se, dessarte, mais com a possibilidade do que com a realidade do primeiro grau de jurisdição"42.

Releva salientar, por outro lado, que, no sistema do direito positivo brasileiro, o princípio do duplo grau não está consagrado de modo rígdo, mas mitigado, ou temperado, em algumas circunstâncias, a bem da ceieridade e economia processuais. Há processos de alçada no âmbito da Justiça do Trabalho (Lei no 5.584/70, art. 20, § 49) ₹ da Justiça Federal (Lei n. ${ }^{\circ}$ 6.825/80, art. 49), a exemplo do quc já ocorria com o Código de 1939 (art. 839). Mesmo o vigente CPC permite a supressão de um grau de jurisdição ao discıpinar a ação rescisória (arts. 488), I e 494). Com efeito, cassada a sentença, preceitua o Código que "o tribunal (...) proferirá, se for o caso, novo julgamento" da causa. Ora, se o princípio do duplo grau fosse levado às suas últimas conseqüências, tocaria ao tribunal tão-somente exercer o "indicium rescissorium". Rescindida, porém, a sentença, e sendo o caso, caberia ao juízo de primeiro grau exercer o "indicium rescindens", prolatando outra sentença de mérito, visto que a anterior juridicamente não há mais. A lei, no entanto, optou por outra solução, que implica o juigamento válido da causa unicamente pelo tribunal.

(42) Ob. cit., Vol. III, pág. 252. 
Não surpreende, assim, que a lei (CPC, art. $515, \S 10)$ também se satisfaça com o exame do mérito "no seu conjunto", como diz LIEBMAN, ainda que sem esgotá-"o, para a efetivação do duplo grau. Preferiu-se sobrepor a tudo o principio da economia processual.

\section{JULGAMENTO INTEGRAL DA CAUSA PELO 'TRT}

Firmadas essas premissas, volvamos, enfim, nossa atenção especificamente sobre o tema proposto. Figuremos um exemplo para melhor compreensão.

Suponha-se que "A" demanda com referência a "B". Pede: horas-extras, férias proporcionais, 13 o salár o proporc onal e aviso prévio. "B", em conestação, argumenta: (a) não havia vínculo empregatício entre as partes, mas típ co contrato de representação comercial, razão por que improcedem todas as verbas; (b) ainda que empregado fosse, não faz juz a horas-extras porque prestava serviço sem sujeição a horár o e fora de sua permanente fiscalização (CLT, art. 62, a); (c) tambérn indevidas verbas rescisórias, pois houve justa causa para ruptura do contrato, consistente na prática de ato de improbidade. Após a instrução, a Junta declara inexistente a relação de emprego, examinando apenas o fundamento (a) da defesa, julgando totalmente improcedentes os pedidos. " $\mathrm{A}$ " interpõe recurso ordinário.

Nesse caso, no que pertine à extensão do efe:to devolutivo, a "matéria impugnada" é a declaração de improcedência dos pedidos, como afirma BARBOSA MOREIRA (supra no IV). O que se devolve ao reexame do Tribunal, assim, não é apenas a controvérsia sobre a relação de emprego. É aí que res:de o primeiro e grave equívoco em que incorrem os Tribunais Regionais do Trabalho no trato desse problema. Ora, parece-me ev'dente, data vênia, que se a sucumbência do autor (A) foi total, a irresignação é contra a sentença como um todo, que repeliu em bloco os pedidos: Ou seja, o recurso é total e, por conseguinte, a devo'ução também é total: cabe ao TRT julgar novamente todos os pedidos (supra no IV). E o que deflui do art. 515, "caput", do CPC.

Quanto à profundidade, sendo sempre amp íssima a devolução, nos termos dos $\S \S 10$ e $2^{\circ}$ do art. 515 , caberá ao tribunal (e não se trata de mera faculdade ante os termos imperativos da lei) apreciar e julgar "todas as questões suscitadas e discutidas no processo, ainda que a sentença não as tenha julgado por inteiro", assim como conhecer dos demais fundamentos da defesa, não solucionados pela sentença. Desse modo, no exemplo, para julgar os pedidos rechaçados pelo juízo "a quo" ("matéria impugnada"), o "material" com que trabalhará o TRT, além das questões 
examináveis de ofício, são os três supracitados fundamentos da defesa: ausência de vínculo (a), inexistência de horas-extras (b) e justa causa (c). O tribunal, então, poderá: "confirmar" a sentença, sob o mesmo fundamento (a), "manter" a sentença sob os fundamentos (b) e (c), ou "reformar" a sentença para declarar existente a relação empregatícia, caso em que lhe toca ir em frente e examinar as demais questões suscitadas pela defesa para acolher ou rejeitar os pedidos de horas-extras e verbas rescisórias.

Imagine-se agora a situação aná'oga da prescrição. "C" demanda com relação a "D". Pede: horas-extras e gratificação. " $D$ " sustenta em defesa: (a) es'ć totalmente prescrita a ação, eis que decorridos mais de dois anos da rescisão e o processo anterior, "arquivađo", não teve o condão de interromper a prescrição; (b) a jornada era normal; (c) a gratificação, paga esporadicamente e sem uniformidade, não se revestia de natureza salarial. A Junía, após a instrução probatória, acolhe a alegação de prescrição total e julga improcedentes os pedidos. "C" interpõe recurso ordinário.

Nessa hipótese, aplica-se "mutatis mutandis" o exposto acima sobre a relação de emprego. Como a impugnação abrange a sentença em sua totalidade, a devolução é plena, ou integral, seja quanto à extensão, seja quanto à profundidade. Obviamente o recorrente não se está insurgindo somente com a prescrição decretada, mas primacialmente com a declaração de improcedência dos pedidos que daí dimana. Logo, sendo total a devolução porque total a impugnação, cumpre ao TRT julgar novamente os pedidos, adotando o mesmo fundamento da sentença ou, dela divergindo, por qualquer outro fundamento ventilado no pedido ou na defesa e não abordado pela sentença.

O que não é admissível sem afrontar a lei, "datíssima vênia", nesses dois casos, é o TRT julgar pela metade a causa e remeter os autos ao juízo "a quo". Ora, este já não equacionou todos os pedidos segundo o seu convencimento? Inquestionável que sim. Claro está que negando o vínculo empregatício o Juízo de primeiro grau está rejeitando todos os pedidos em face da ausência da relação jurídica que lhes serve de suporte. Claro está, semelhantemente, que pronunciando a prescrição total da ação por via oblíqua o juízo repele também todos os pedidos. Em um caso e em outro, portanto, profere o juízo sentença de mérito, relativamente aos pedidos deduzidos. A lei, nesse sentido, é expressa, como visto (CPC, arts. 269, I e IV). Tanto tais pedidos foram julgados que se porventura não se interpuser recurso ninguém duvida que a sentença, em ambos os casos, produzirá coisa julgada material (CPC, arts. 467/468), impedindo reexame n'outro processo. É, inclusive, suscetível de rescisória (aliás, não foi outra a razão pela qual o legislador reputou "de mérito" a sentença que declara 
a prescrição). Se, portanto, todos os pedidos foram julgados mediante sentença válida como ato processual, nada justifica a restituição dos autos para que se "julgue o mérito como entender de direito". Pois já houve julgamento de méritos sem qualquer vício procedimental!

Argumenta-se com "supressão de instância". Ledo engan’ também, como demonstramos exaustivamente no item anterior. Repita-se: o princípio do duplo grau concerne aos pedidos não às questões. E, na espécie, os pedidos foram julgados, reafirmo, ainda que prejulgados, ou, como diz LIEBMAN, julgados "no seu conjunto". Isso, a toda evidência, não é o mesmo que o juizo abster-se de julgar. Uma coisa é julgar-se aquém do(s) pedido(s) (sentença "citra petita"); outra, bem diversa, é julgar-se todos os pedidos, embora sem apreciar todas as questões ou fundamentos da defesa. Por isso que absolutamente distintas, não se pode, como vem sucedendo, dispensar a ambas as situações o mesmo tratamento: naquela não cabe ao tribunal "integrar" a sentença pronunciando-se sobre pedidos em que foi omissa, sob pena de violar-se o duplo grau; nesta, todavia, incumbe ao TRT simpiesmente rejulgar os pedidos.

Em realidade, nas hipóteses figuradas, o tribunal, à vista da prova coligida em primeiro grau, age como se fora "uma segunda primeira instância", conforme consagrada expressão.

Tem inteira oportunidade relembrar aqui a feliz imagem criada por CARNELUTTI:

"L'appello é una forma di rinnovazione. Il processo si rifá. Non si ripara l'edifizio già costruito, si ricostruisce" ${ }^{\text {"3. }}$.

Eis tudo: o tribunal não repara, mas reconstrói o edifício já construido.

A lei brasileira abona essa magnífica lição, não apenas pelas normas do art. 515 e parágrafos, como também ante o que reza o art. 512, do CPC, aplicável à apelação contra sentença de mérito válida e, pois, as hipóteses trazidas à colação:

"Art. 512. O julgamento proferido pelo tribunal substitui a sentença ou decisão recorrida no que tiver sido objeto de recurso".

(43) v. FRANCESCO CARNELUTTI, "Lezione di Diritto Processuale Civile", Vol. IV, Pádova, 1931, pág. 232. 
Ora, "substituir" não é "reformar" (como se costuma dizer, impropriamente) a sentença sem equacionar os pedidos e restituir os autos ao primeiro grau; é julgar novamente a causa (não a sentença) e pôr em lugar da sentença o acórdão, acolhendo ou rejeitando os pedidos.

O festejado e saudoso PONTES DE MIRANDA narra um caso análogo, igualmente de improcedência total, que corrobora minha argumentação:

"Se o juiz, na ação de reivindicação, nega a reivindicatória, por qualquer fundamento, inclusive por lhe parecer que a pretensão do autor é outra, nada mais tem que julgar por quanto o seu julgamento foi exauriente $(=$ pela improcedência do pedido). Após o que julgou, nada mais pode julgar o juiz; esgotou todo o conteúdo do pedido. Se essa sentença vai a exame de tribunal e essa manda que o juiz julgue, o tribunal, a quem foi devolvido, por se tratar de apelação, todo o conhecimento do feito, viola, sem qualquer dúvida, o art. 515. Aliás, só não se conhece do resto do mérito quando a decisão na prejudicial fecha as portas para isso (art. 560). (...)

Se o juiz nega a pretensão ou ação, que o autor alega como 'res in iudicium deducta', o tribunal, a que vai o recurso de apelação, se reforma a sentença, tem de julgar o feito" 4 .

Como se constata, os dados lógicos deste exemplo são os mesmos daqueles que narrei anteriormente, não podendo conduzir a inferências lógicas distintas.

Em suma: ao dar provimento a recurso ordinário, por entender configurada a relação de emprego ou incorrente a prescrição, o vezo dos TRTs de remeter os autos ao juízo de primeiro grau para "julgar o mérito", ao revés de julgar integralmente a causa, data vênia, destoa da boa técnica e infringe a lei.

A meu ver, acórdão assim proîerido é, inclusive, passível de ser atacado mediante ação rescisória (CPC, art. 485, V, c/c arts. 515,512 e 131).

\section{OFENSA A PRINCIPIOS CARDEAIS DO PROCESSO}

A praxe apontada e sedimentada nos TRTs, sobre violar a lei, atenta contra princípios basilares do processo, como o da persuasão racional do juiz, da economia e da celeridade.

(44) PONTES DE MIRANDA. "Comentários ao Código de Processo Civil", Tomo VII, Forense, 1975, pág. 212. 
Em primeiro lugar, aniquila o princípio da convicção racional do juiz, ou do livre convencimento na apreciação e valoração da prova produzida nos autos, adotado pela nossa lei (CPC, art. 131). Com efeito, se o juiz, avaliando a prova, em sentença válida, conclui que o autor não era empregado, ou que está prescrita a ação e, por isso, rejeita os pedidos, não se pode, sem grave e ilegal constrangimento do magistrado, compeii-lo a examinar novamente os pedidos já julgados, bem ou mal.

Certo, é admissível, muitas vezes, determinar ao juiz que profira nova sentença, ou porque extinguiu o processo sem julgamento de mérito quando não deveria fazê-lo, ou porque proferiu sentença de mérito inválida, ou, em processo inválido. Mas releva notar que são todos casos de vício procedimental do juiz ("error in procedendo"). Por isso, justifica-se que o tribunal, cassando a sentença, ordene que outra se prolate, escoimada do vício procedimental. A hipótese de que cuidamos aqui, todavia, é muito diferente: trata-se de sentença de mérito válida, prolatada em processo também inválido, na qual, ao ver do tribunal, constatou-se "error in iudicando" (juízo de mérito equivocado) decorrente da má apreciação da prova, ou de errônea aplicação do direito, ou de ambos. Como, então, sem violentar a convicção e a consciência do julgador, impor-lhe $\mathrm{c}$ dever de sentenciar de novo a causa? Vou mais longe ainda: penso que o juiz prolator da sentença nem pode julgar outra vez a lide. Entendo que está mesmo impedido de fazê-lo diante do que dispõe o art. 134, III, do CPC. Se a ?ei proíbe o juiz de julgar, no tribunal, o processo "contencioso ou voluntário" de que conheceu e deciaiu em primeiro grau - estabelecendo aí uma presunção absoluta de parcialidade do juiz -, como conceber que o mesmo juiz julgue validamente duas vezes a mesma causa em primeiro grau? Os casos são quase idênticos, e é forçoso convir: as razões que ditaram ao legislador a fixação do impedimento em tela induvidosamente concorrem em amoos os casos. De fato, é bastante razoável presumir a parcialidade do juiz nessa situação. É claro como a luz solar: já havendo decidido que fulano não é empregado de beltrano, ou que sua ação está prescrita, a tendência natural do juiz, humanamente compreensível, consciente ou inconscientemente, será rejulgar " com hoa dose de má vontade os pedidos e rejeitá-los. Seu raciocín:o fatalmente será este: como posso acolhcr pedidos de férias, 13 o salário, etc. em favor de alguém que não considero empregado? Em uma palavra: o desrespeito ao seu livre convencimento decerto irá retirar-lhe a isenção e a serenidade necessárias ao novo julgamento. Deve, por isso, abster-se de atuar no processo e, se tal não se der, poderá ser recusado pela parte (CPC, arts. 137 e 304). 
Em segundo lugar, a postura em apreço é conđenável porque conspira contra o princípio da economia processual. O processo do trabalho, mais que qualquer outro, deve nortear-se pelo ideal de outorgar aos jurisdicionados uma đistribuição de justiça, tanto quanto possível, barata e rápida. O princípio aludido recomenda a obtenção do máximo de resultado na atuação do direito com o mínimo de esforço, ou de atividades processuais. Naturalmente, a remessa dos autos ao juízo "a quo" para outro julgamento redundará em novas despesas às partes e ao Estado (nova sentença, novo recurso, novas custas, eventualmente exigência de depósito etc.). Tudo perfeitamente evitável e desnecessário. (...)

Em terceiro lugar, a orientação focalizada dos TRTs ofende o princípio da celeridade processual, tão decantada e de que é tão cioso o processo trabalhista, por bons motivos. Não se divisa o porquê de o TRT, podendo obviar a morosidade, prefere consagrar uma solução que, convenhamos, praticamente nada soluciona: só retarda o julgamento definitivo da lide, em prejuízo da paz social. Imagine-se que em qualquer dos exemplos que trouxe à colação no item anterior alegue-se em defesa: preliminarmente, coisa julgada; no mérito, (a) inexistência de vínculo empregatício, (b) prescrição total e (c) justa causa. Suponha-se que a Junta acolha a preliminar de coisa julgada, extinguindo-se o processo sem ju'gamento do mérito (CPC, art. 267, V). O tribunal dá provimento ao recurso ordinário interposto e manda prosseguir, por entender diferentemente. Como não pode adentrar desde logo no mérito da causa, volvem os autos à Junta. Esta, no mérito, declara inexistente a relação de emprego. Novo recurso, novo provimento e voltam os autos à Junta. Agora esta afirma a prescrição total da ação. Novo recurso, novas despesas, novo provimento e retornam os autos ao juízo "a quo". Finalmente, julgada a justa causa, somente então, no quarto recurso o TRT vai dirimir o litígio integralmente. Ora, por que acarretar essa verdadeira "via crucis" aos litigantes? Acaso Justiça tardia não é denegação de Justiça ou, no dizer de RUI, "injustiça qualificada"? O exemplo acima pode ser um tanto acadêmico, mas não impossível de configurar-se concretamente. De resto, ainda que seja um só recurso a mais, ninguém ignora o quanto isso importa em demora e gastos, tudo sem justificativa plausível.

\section{A JURISPRUDENCIA DO STF E DE OUTROS TRIBUNAIS}

O Supremo Tribunal F'ederal tem aplicado, inflexivelmente, o princípio do duplo grau de jurisdição nos casos em que o juízo "a quo" examina apenas questão preliminar, sem entrar no mérito 
da causa, e o juízo "ad quem", ao julgar o recurso, ultrapassa a questão preliminar e julga o mérito ${ }^{45}$. Essa efetivamente a orientação correta.

Entretanto, se o primeiro grau ao menos iniciara o julgamento do mérito, conquanto não seja pacífica a jurisprudência do STF, parece inclinar-se por adm tir que o juízo "ad quem" conheça de questões referentes ao mérito não enfrentadas pela sentença. Esta foi a tese vitoriosa na Suprema Corte ao julgar o

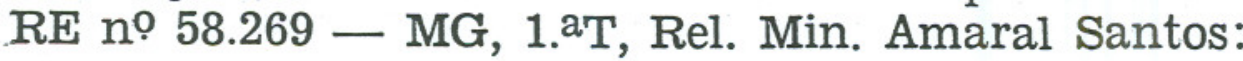

"EMENTA. Recurso extraordinário não conhecido. Embora não ventilada na sentença parte do pedido, o efeito devolutivo da apelação permite que dela se tomasse conhecimento no julgamento do recurso. Inexistência de ofensa aos arts. 40 e 824, do Código de Processo Civil, e divergência jurisprudencial não conprovada"46.

Tratava-se aí de ação de anulação de compra-e-venda fundada em: a) incapacidade da outorgante; b) vício de forma. A sentença omitiu-se totalmente quanto ao segundo fundamento e julgou improcedente a pretensão. O TJ deu provimento à apelação para declarar nula a escritura pelo vício de forma, isto é, por fundamento que não havia sido cogitado pela sentença. No $\mathrm{RE} \mathrm{n}$ 0 58.269, interposto contra o acórdão o STF, por sua 1.a Turma, firmou a decisão cuja ementa consta acima. Proposta ação rescisória contra este último acórdão, o Excelso Supremo Tribunal Federal, em sessão plenária, por unanim dade, julgou-a improcedente, assentando:

"Desde que a sentença de primeiro grau seja decisão sobre o mérito (...) não está o tribunal, ao julgar a apelação, adstrito às questões decididas na sentença de primeiro grau, mas pode apreciar ainda as que, nos limites do pedido, foram suscitadas $e$ discutidas pelas partes" ${ }^{\prime 7}$

(...)

- Inexistência de ofensa ao princípio do duplo grau de jurisdição. Aplicação do art. 824, do Código de Processo Civil de 1939".

Prevaleceu o voto do eminente Relator, Min. Moreira Alves, do qual se destaca este tópico:

(45) V. No RE n.0 103.588 - SC decidiu-se: "Extinto o processo sem julqamento do mérito $(\ldots)$, com base no art. 267, VI, do $\mathrm{VI}$, do CPC, não é possível ao juízo de segunda instância, em grau de apelacão, apreciar o mérito, julgando procedente a ação, sob pena de comprometer o duplo grau de jurisdição" (RTJ 112, pág. 935). Assim também: RE 71.515, RTJ 60/207; RE 72.352, RTJ 60/828.

(46) Excertos do acórdão estão transcritos in RTJ 86/70.

(47) RTJ $86 / 87$. 
No RE no 8.231, Rel. Min. Luiz Gallotti, e no RE no 10.257, Rel. Min. Orosimbo Nonato, já decidiu o STF, respectivamente:

"Pode o juiz da apelação se ocupar de questões não examinadas na primeira instância; examina todos os aspectos que podiam, para o primeiro juiz, constituir objeto de exame"48.

"A apelação devolve integralmente ao juiz de segunda instância o conhecimento da causa, repondo as partes nas condições em que se encontravam quando da contestação da lide. $O$ juiz da apelação julga de direito $e$ de fato, tendo sob suas vistas as questões, mesmo as omitidas pelo juiz "a quo". Se o juiz da apelação conhece da causa em toda a extensão, sua sentença é que se torna suscetível de execução, pois substitui, no que tiver sido objeto de recurso, a sentença apelacia". ${ }^{48}$

Em outra ocasião decidiu o STF:

"A instância de apelação a leí devolve íntegro o conhecimento de todas as questões suscitadas e discutidas na causa mesmo daquelas não resolvidas em sentença"49.

É importante observar que todas essas decisões foram tomadas aplicando o Código de 1939, que, como se viu, não continha disposições tão explícitas como a dos $\S \S 1$ e e 2 , do art. 515 do CPC atual.

N'outros tribunais, não obstante controvertida a matéria, já se decidiu, com acerto, sob a égide do Código em vigor:

"As questões e fundamentos a que aludem os $\S \S 1$ e e 2 ? do CPC compreendem as indagações e as razões jurídico.legais. Se o juiz não resolveu todas as indagações suscidas ou discutidas, ou não as resolveu por inteiro, serão todas e por inteiro objeto de apreciação e solução pelo Tribunal. Se o juiz acolhe apenas um dos fundamentos; todos os demais serão devolvidos ao conhecimento do Tribunal...50.

Dentre os TRTs, o único que parece afinar-se a esse diapasão é o da $1 .^{a}$ Região:

(48) Referências feitas no RE 64.107, in RTJ 52/184.

(49) DJU de 18/10/1962/3.048, apud Alexandre de Paula, Vol. II, 1.'ed., 1977, pág. 528, "Código de Processo Civil Anotado".

(50) Ac. unân. da 5. Cam. do TJSP, de 10/10/74, in Alexandre de Paula, ob. cit., pág. 530. 
"Assiste razão ao recorrente na pretensão de não retornarem os autos à Junta, para decisão do mérito. É que o mérito - prescrição - já foi parcialmente apreciado e, portanto, a espécie cabe no preceito contido no art. 515 $\S 1$ do $C P C$ ' ... ainda que a sentença não as tenha julgado por inteiro", já que inclusive suscitados outrus aspectos meritórios. A baixa ao Juízo de origem, para julgamento do mérito seria providência contraditória por determinar uma apreciação já realizada, ainda não por inteiro, na linguagem do processo comum; com aplaudida aplicação subsidiária no caso, pela celeridade que o mesmo proporciona. Ademais, vio'entaria a convicção do julgador "a quo" impor-lhe o proferimento de nova sentença de mérito, quando sobre ela já decidiu, de modo formalmente perfeito sem vício de procedimento" ${ }_{51}$.

Bem andarão os demais TRTs se palmilharem nesta trilha.

\section{CONCLUSÕES}

Em decorrência, conclui-se:

1. A amplitude do efeito devolutivo do recurso ordinário delimita-se: a) quanto à extensão: à matéria impugnada; i) quanto à profundidade: é sempre integral compreendendo questões suscitadas e discutidas no processo, mesmo que não julgadas inteiramente pela sentença, ou fundamentos do pedido, ou da defesa não acolhidos pelo juízo "a quo";

2. O princípio do duplo grau de jurisdição pertine aos pedidos, não às questões, não reclamando o exame exaustivo da matéria de mérito pelo juízo "a quo";

3. Se o TRT conhece e dá provimento a RO interposto contra sentença declaratória da improcedência total dos pedidos, fundada na existência de vínculo empregatíc ${ }^{\circ}$, ou na ocorrência de prescrição, não lhe é lícito apenas "reformar" a sentença nesse particular e determinar a remessa dos autos ao juízo "a quo" para "julgar o mérito", pois:

a) já proferida sentença julgando o mérito da causa "no seu conjunto";

b) a declaração de improcedência é a "matéria impugnada" no apelo e, assim, a devolução é total da causa ao TRT, incumbindo-lhe julgá-la como se fora "uma segunda primeira instância"; para isso pode julgar questões (não ped dos) não julgadas pelo órgão "a quo";

(51) TRT 1.' Reg., 3.' Turma, de 10/07/78. Rel. Juiz Fiorêncio Júnior, in Dicionário de Decisões Trabalhistas, Bonfim, 16. ed., pág. 484. 
c) o princípio do duplo grau de jurisdição refere-se aos pedidos, não às questões; e aqueles foram todos julgados, conquanto omissa a sentença acerca de outras questões de mérito;

d) toca ao TRT "substituir" a sentença recorrida.

4. Se o TRT, em casos como os do item anterior - julgados todos os pedidos, embora não todas as questões suscitadas no processo - cinge-se a "reformar" a sentença e ordenar a restituição dos autos ao primeiro grau a fim de que "julgue o mérito":

a) infringe a lei, tornando rescindível o acórdão;

b) conflita com a tradição do nosso Direito, a mais prestigiosa doutrina e a jurisprudência majoritária do STF para casos análogos;

c) afronta princípios básicos do processo, como o do livre convencimento do juiz, da economia e da celeridade;

d) interpreta e aplica erroneamente o princípio do duplo grau de jurisdição;

e) cria impedimento ao magistrado "a quo" prolator da sentença, gerando uma presunção absoluta de parcialidade para julgar novamente a causa; deve abster-se de fazê-lo e pode ser recusado pela parte. 